\title{
Büyük Veri Reklamlarında İkna Sürecinin Çift Süreç Teorileri Bağlamında İncelenmesi
}

Bašvuru Tarihi: 15.01 .2021 Yayın Kabul Tarihi: 24.03.2021 Yayınlanma Tarihi: 30.04 .2021

\author{
Anıl Durmuşahmet ${ }^{1}$ \\ istanbul Üniversitesi, Sosyal Bilimler Enstitüsü, \\ Halkla iliş̧kiler ve Tanıtım Bölümü, İstanbul \\ anildurmusahmet@gmail.com \\ ORCID: 0000-0003-3601-188X
}

öz

ikna, reklam söz konusu olduğunda her zaman önemli ve popüler olmayı başaran bir kavramdır. Çünkü reklamın temel amaçlarından olan satış vaadinin gerçekleşmesi hedef kitlenin ikna edilmesine bağlı şekilde gerçekleşmektedir. Bu durumun farkında olan reklamcılar ve reklam verenler çok sayıda teknik geliştirmiş olsalar da günümüzde akıllı telefonlarına bağımlı ve sürekli olarak sosyal medyada vakit geçiren insanlar için pek çok teknik elverişsiz kalmaktadır. Bu amaçla büyük veri - hedefli reklamcılık ortaya çıkmıştır. David Carroll'un Facebook'tan kişisel verilerini istemesi ve ardından Cambridge Analytica şirketinin Amerika başkanlık seçimleri ve Brexit sürecinde oynadığı rol büyük veri - hedefli reklamcılığın önemini ve etkisini ortaya çıkarmaktadır. Sosyal medyanın görsellik üzerinden ilerleyen ve algılara direkt etki eden yapısı sayesinde klasik kitle iletişim araçlarında, reklam faaliyetlerinden daha başarılı olan bu yeni reklamcılık faaliyetlerinde kişilerin sezgileri üzerindeki etki ve büyük veri üzerinden düşünüldügünde ince detaylar üzerinden işleyerek güçlü bir iknayı ortaya koymaktadır. Buradan hareketle iknanın nasıl işlediğine yönelik temel bir sistem sunan Çift Süreç Teorileri kapsamında, sosyal medyada yer alan büyük veri reklamlarına yönelik düşüncelerin incelendiği bu çalışma ile insanların düşüncelerinin nasıl değiştirilmeye çalışıldığı ve yine bu reklamlar aracılığıyla insanların nasıl sürekli olarak tüketime yönlendirilmeye çalışıldığı aktarılmaktır. Nitel araştırma yöntemleri kapsamında yer alan derinlemesine görüşme tekniği kullanılarak gerçekleştirilen araştırmada, kişilerin duygularına yönelik yollar olan çevresel yol ve sezgisel işlemenin, sosyal medya reklamlarında hedef kitleyi etkileme konusunda çok daha etkili olduğu; kişilerin daha önceki sosyal medya ve internet tercihlerine göre nokta atışı reklamlar aracılığıyla kişiye özel reklam gösteriminin gerçekleştirildiği gözlemlenmiştir.

Anahtar Kelimeler: Çift süreç teorileri, ikna, sosyal medya, büyük veri, veri madenciliği.

\footnotetext{
${ }^{1}$ Doktorant
} 


\title{
Investigation of Convincing Process in Big Data Advertisements in the Context of Dual-Process Theories
}

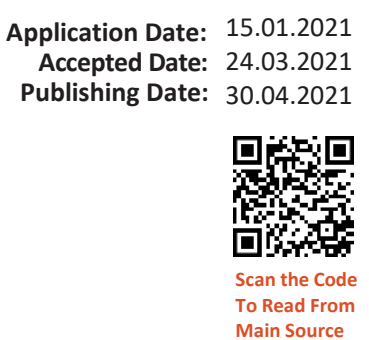

\author{
Anıl Durmuşahmet ${ }^{2}$ \\ Istanbul University, Institute of Social Sciences, \\ Department of Public Relations and Publicity, istanbul \\ anildurmusahmet@gmail.com \\ (D) ORCID: 0000-0003-3601-188X
}

\begin{abstract}
Persuasion is a concept that has always been important and popular when it comes to advertising. Because the realization of the promise of sale, which is one of the main purposes of advertising, depends on the persuasion of the target audience. Although advertisers and advertisers who are aware of this situation have developed many techniques, many techniques remain unfavorable for people who are dependent on their smartphones and spend time on social media constantly. For this purpose, big data targeted advertising has emerged. David Carroll's request for personal data from Facebook and the subsequent role played by Cambridge Analytica in the US presidential election and Brexit process highlights the importance and impact of big data-targeted advertising. Thanks to the structure of social media that progresses through visuality and directly affects perceptions, these new advertising activities, which are more successful than advertising activities in classical mass media tools, reveal a strong persuasion by processing through fine details when considered through the impact on people's intuition and big data. From this point of view, within the scope of Dual-Process Theories, which offers a basic system for how persuasion works, it is to convey how people's thoughts are tried to be changed with this study, which examines the thoughts about big data advertisements on social media, and how people are constantly trying to be directed to consumption through these advertisements. In the research, which was carried out using the in-depth interview technique within the scope of qualitative research methods, it was found that the environmental path and intuitive processing, which are ways of people's emotions, are much more effective in influencing the target audience in social media advertisements; According to the previous social media and internet preferences of the people, it was observed that personalized advertisements were displayed via pinpoint ads.
\end{abstract}

Keywords: Dual-process theories, persuasion, social media, big data, data mining.

\footnotetext{
${ }^{2}$ Ph.D. Student
} 


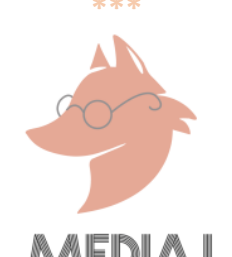

\section{Giriş}

İknanın temel bir metodoloji olarak kullanıldığı reklamcılık, çağın gereksinimlerine uyma konusunda oldukça başarııdır. Medya ve internet teknolojilerindeki hızlı değişimler ile kendini sürekli olarak güncelleyen reklamcllık son olarak büyük veriden yararlanarak hedef kitlede istediği davranış değişikliğini gerçekleştirmektedir. Özellikle kendini “izleyici davranışını değiştirmek için verileri kullanan küresel seçim yönetimi ajansı" (Risso, 2018, s. 75) ya da bizzat CEO'su tarafından "davranış değişikliği ajansı" (Nix, 2016) olarak tanımlayan Cambridge Analytica hedefli reklamcılığı etkin şekilde kullanarak insan ruhuna ${ }^{3}$ bizzat etki etmeyi başarmıştır. Büyük veriye dayalı hedefli reklamcılık insan ruhuna etkisini kendine bir zemin olarak seçerken, kullanıcıyı kendisi için gerekli verilere daha kolay ulaşmasına olanak sağlayarak, sürekli bir gözetime ve bu gözetime bağlı olarak, politik ve pazarlama amaçlı ikna taktiklerine maruz bırakmaktadır.

İkna taktiklerine ve ikna edilme sürecine yönelik en temel verileri sağlayan Çift Süreç Teorileri'nden (Suher, 2017, s. 22) Detaylandırma Olasılık Modeli (ELM, Elaboration Likelihood Model) ve Sezgisel Sistematik Model'de (HSM, Heuristic Systematic Model) yer alan çevresel yol ve sezgisel işleme modları bu reklamcılık faaliyetlerindeki hedef kitlenin ikna sürecini anlamakta oldukça önemli bir teorik çerçeve sunmaktadır. Gawronski ve Creighton'e (2013) göre sosyal muhakeme ve davranışların altında yatan zihinsel süreçleri ele alan bu teoriler iknanın otomatik mi yoksa kontrollü bir şekilde mi gerçekleştiğini ortaya koymaya yardımcı olurken, ele alınacak büyük veri reklamcılığındaki ikna sürecini anlamada yol gösterici bir işleve sahip olarak kullanılmıştır. Cambridge Analytica'nın ihbarcı- itirafçısı olan Brittany Kaiser'in kongre karşısında sarf ettiği "silah kalitesinde iletişim taktikleri" (Amer ve Noujaim, 2019) içerisinde yer alan veriler hem geçmişte hem bugün hem de gelecekte insanlar için oldukça tehlikeli olacaktır. Bu verilere dayalı şekilde gerçekleştirilen reklam dağıtımı ise kitleyi kontrol etmek ve istenilen davranış değişikliğini gerçekleştirmede reklam veren ve reklam kurumlarına kolaylık sağlayacaktır. Fuchs ve diğer pek çok kişinin dediği üzere 21. yüzyılın petrolü olan bilgi çok değerlidir (Aksu, 2016, s. 10) ve bu anlamda da bu verilerin nasıl değerlendirilerek kitle üzerinde iknanın gerçekleştirildiğinin anlaşılması gerekmektedir.

Çalışma kapsamında amaç, günümüz insanının hayatının temel yapı taşlarından biri haline gelen sosyal medyada kişilerin sürekli olarak bilinçli ve bilinçsiz olarak karşılaştığı büyük veriye dayalı reklamların, insanları Çift Süreç Teorileri bağlamında hangi yol ve işlev bağlamında ikna ettiğini ortaya koymaktır. Araştırma nitel paradigmaya dayalı derinlemesine görüşme tekniğiyle elde edilen verilerin yorumsamacı yaklaşımla analiz edilmesi sonucunda gerçekleştirilmiştir.

\footnotetext{
${ }^{3}$ Risso (2018)'in makale başlığına atfen kullanılan bu ifade aynı zamanda David Carrol'un Cambridge Analytica sürecini ele alan The Great Hack (Amer ve Noujaim, 2019) belgeselinde de geçmektedir.
} 


\section{ÇiFT SÜREÇ TEORILERI PERSPEKTIFINDE REKLAMIN IKNA SÜRECi}

İknayı anlama ve değerlendirme konusunda oldukça önemli ve etkili olan Çift Süreç Teorileri (Gass ve Seiter, 2018, s. 96) ikna konusunda en temel yapıyı ortaya koymaktadır. Insanları ikna etmede tarih boyunca pek çok metot geliştirilmiş olmasına karşın Çift Süreç Teorileri iknanın nasıl geliştiği konusunda ikili yollar ortaya koyarak, iknanın anlaşılabilirliğini arttırmayı hedeflemektedir.

Bir iletişim süreci olarak kabul edilen ikna, "bir kanaati kabul ettirme, bir kanaat uyandırma, inanmasını sağlama, razı etme" (TDK Sözlük, 2021) şeklinde tanımlanmaktadır. İknada karşı taraf üzerinde bir tutum, yargı ve davranış değişikliği oluşturma temel amaç olduğu için, başarılı bir iknanın gerçekleşmesi 'sonuç'a bağlıdır. Süreç içerisinde ikna olmuş gibi gözüken bir kişi süreç sonucunda bir satın alma ya da davranış değişikliğine gitmiyorsa iknanın başarılı olduğunu söylemek doğru olmaz. Çünkü ikna etkileme çabasını değil, bu etkileme çabasının sonucunu ifade eder (Suher, 2017, s. 14) ve bu sonucun başarılı olması iknanın gerçekleştiğini gösterir ki en temel amaç, iknanın tam olarak başarıya ulaşmasıdır. Zaten yarım kalmış olması, yani gerekli etkinin ya da davranış değişikliğinin gerçekleşmemesi, ikna sürecinin tamamlanamadığı anlamına gelmektedir (Karadoğan Doruk, 2015).

İknadaki bu etkileme çabasını arttıran etkenler önemli bir çalışma alanına tekabül eder. En temel çalışmalardan birisini Aristoteles ortaya koymuştur. Onun Retorik adlı eserinde ortaya koyduğu Ethos, Pathos ve Logos ikna kabiliyeti yüksek olarak tanımladığı karizmatik kişilerde bulunması gereken etkenlerdir. Ethos- karizma, sözlü ve sözsüz iletişim becerisini bir diğer deyişle etkiyi ve etki gücünü ortaya koymakta; pathos olarak adlandırılan erdemler, bilgelik, sağduyu ve cesareti ve son olarak logos mantığı, mantıklı düşünmeyi ortaya koyar (Aristoteles, 2014). Bu üç etkenin bulunduğu kişi/ kişiler ikna kabiliyeti yüksek kişilerdir. İkna kabiliyetinin en önemli alanlardan birisi olan reklam sektöründe de retorikten yararlanılmaktadır.

Reklam, teknik olarak ikna amaçlı gerçekleşen film, tanıtım vb. şeklindeki faaliyetlerden meydana gelir. Bu faaliyetlerin sonucunda iknanın gerçekleşmiş olması ve satın alma, hizmet tercihi ya da oy yöneliminde değişimin gerçekleşmesi beklenir. İkna seçiminin özgürce yapılması yani dayatılmaması oldukça önemlidir. Bu konuda propagandanın bile ikna için bir dayatma yerine manipüle etme yeteneğinden faydalandığını söylemek mümkündür. Fikirlerin kabul edilmesi, inanç sistemini de içererek gerçekleşir böylece çeşitli semboller üzerinden çalışan ikna, hedef grubun inanç sistemine etki eder (Suher, 2017, s. 16) ki böylece ikna çok daha güçlü gerçekleşir.

Çift Süreç Teorileri (Dual-Process theories), sosyal bilişte (social cognition) son 30 yıl içerisinde yer alan pek çok araştırmada kullanılmıştır. Bu teoriler ikna sürecini iki ana kategoride inceleyerek bu kategorilerin kendine özgü işleyişlerini ele alırlar. Araştırmacılara göre Çift Süreç 


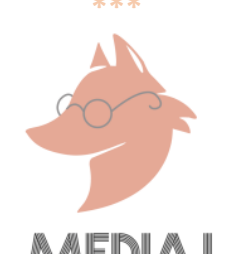

Teorilerinin yönlendirmesi olmadan çağdaş psikoloji alanında çalışmaların yönelmesi gereken noktaları tahmin etmek oldukça güçleşecektir (Suher, 2017, s. 22). Sosyal medyada yer alan reklamlara ait ikna sürecinin incelendiği bu çalışmada da ikna sürecini etkileyen noktaların bulunması ve incelenmesi gerektiği için Çift Süreç Teorileri tercih edilmiştir. Çift Süreç Teorilerinin, diğer ikna teori ve modellerinde olduğu gibi sadece mesajı ve içeriğini temel almadığını ayrıca mesajın hangi durum ve şartlarda hedeflenen değişimi gerçekleştireceğini de ele aldığını belirten Fennis ve Strobe (2010) çalışmalarında, hedeflenen kişi veya grupların ilgi düzeyinin iknada temel bir argüman olduğunu ele almaktadırlar.

Çift Süreç Teorilerinde bir olay iki farklı sürecin sonucunda neticelenir. Bu iki süreçten biri açık bir şekilde gerçekleşirken; diğerinin gizli şekilde gerçekleşmektedir. Karar verme süreci içerisinde yani ikna sürecinde aynı anda pek çok olgunun üzerinde duran insan zihninde yaşanan ekonomik, psikolojik, sosyolojik düşünler bu teori ile açıklanmaya çalışılır. Bu açıklamalar yapııırken kişilikte ön planda tutulur. Çünkü ikna sürecinde kişilik ikna yetisine direkt etki eder (Seker, 2014, s. 2).

Çift Süreç Teorilerinde genel olarak iki model öne çıkmaktadır: ELM ve HSM olarak kısaltılan bu modeller birbirlerine hem benzemekte hem de bazı yönleriyle ayrılmaktadır. Bu kısaltmaları açacak olursak; ELM'nin, ikna literatüründe en fazla kaynak gösterilmiş model olarak, 1970'li yıllarda Petty ve Cacioppo tarafından geliştirilmiş olan Detaylandırma Olasılık Modeli'dir (Elaboration Likelihood Model) ve literatürde kimi zaman İnce Eleme Sık Dokuma Modeli olarak geçmektedir. Kendi içerisinde süreci merkezi yol ve çevresel yol olarak ikiye ayrılmıştır. HSM ise Shelly Chaiken ve Alice Eagly tarafından geliştirilen Sezgisel Sistematik Modeldir (Heuristic Systematic Model). Bu model de kendi içinde sistematik işleme ve sezgisel işleme olarak ikiye ayrılır. Merkezi yol, sistematik işleme ile çevresel yolda sezgisel işleme ile benzerlikler gösterir (Suher, 2017, s. 47). Bu yol ve işlemeler iknanın işleme sürecini anlamakta kullanılırlar. Bu doğrultuda bir konu ile ilgili olarak kitlede gerçekleştirilmek istenen ikna çalışması hangi yolları ve yöntemleri tercih ettiği anlaşılır kılınarak yol gösterici olmaktadır. Perloff (2014) ELM için ikili bir olasılıktan söz ederken bu ikiliği her iki model içinde genişleterek şu şekilde ele almak mümkündür; Çift Süreç Teorileri'nde genel anlamla ayrıntılı düşünmeye yönelik olarak iknanın gerçekleşme durumunun yanında bir de duyguların ağır bastığı ve detaylandırmanın geri planda tutulduğu bir olasılık bulunur. Bu olasılıklar, moral değişimi üzerinden hareket edersek; moralin olumlu yönde değişimiyle iknanın gerçekleştiği ve tam tersi durumda da ikna sürecinin yarım kaldığını söylemektedir.

Moral değişikliği üzerinden şekillenen iknanın oluşumunda yaşanan, odaklanılmış, konsantre olunmuş bir düşünce düzlemi ile bir de kişinin bu düşüncesini etkileyen arka planı bulunurken ikna, bahsi geçen bu arka planın üzerine şekillenir (Gass ve Seiter, 2018, s. 29). Düşünce düzlemi pek çok çalışmada ortaya konulmasına karşın arka plan özellikle Çift Süreç Teorileri'nin üstünde durduğu bir konudur. Çift Süreç Teorileri'nde bir kişi bir marka ile ilgili geçmiş 
deneyimlerine dayanarak yüzeysel bir karar alabileceği gibi; öncesinde hiçbir deneyimi olmayan bir başka kişi bunu detaylıca inceleyerek ya da bir dost-arkadaş tavsiyesi ile de alabilir. Süreç içerisindeki bu değişim, ELM ve HSM'nin temel çıkış noktasını ortaya koyarken, aynı zamanda mesaja yönelik alıcıdaki durumu da analiz etmeyi sağlamaktadır (Gawronski ve Creighton, 2013).

ELM ve HSM modellerinin her ikisinde de bir bilginin mesaj argümanına yönelik yoğun ayrıntılı düşünme gerektiren durumların fikir veya tutum değişimini ürettiği bir yol bulunmaktadır. Bu yol, Detaylandırma Olasılık Modeli - ELM'de merkezi yol; Sezgisel Sistematik Model - HSM'deki sistematik işleme olarak geçmektedir (Gass ve Seiter, 2018). Merkezi yol ve sistematik işlemede amaç kişide gerekli alt yapının oluşmasını sağlamaktır. Bu altyapı oluştuğu zaman bu yol ve işlemeye göre ikna gerçekleşecektir. Büyük veri reklamlarında ele alınan bu metot uzun vadede gelişen bir ikna sürecini içerir. Bununla birlikte bu yol ve işleme daha etkin ve uzun süreli bir iknayı beraberinde getirir. İknadan dönüş daha zordur (Suher, 2017, s. 57). İknadan dönüşün zorluğuna yönelik olarak Kruglanki (2004, s. 103-104), iknanın kısa ya da uzun süreli bir davranış sürecine işaret ettiğini söylemekte ve bu sebeple gerçekleşmiş olan iknanın dönüşmesinin ya da geriye dönmesinin yeni bir ikna sürecinin başlangıcı olduğunu belirtmektedir. Bu da yeniden iknaya yönelik yol ve işlemelerin devreye girmesine yol açmaktadır.

Merkezi yol ile sistematik işlemenin tam tersi şekilde, mesaj argümanlarına yönelik ayrıntılı düşünmeyi sınırlandırarak, fikir veya tutum değişimini, duygular ve etkisinde kalma gibi çeşitli şekillerde gerçekleştiren bir diğer yol daha bulunur. Bu yol ELM'de çevresel yol ve HSM'de ise sezgisel işleme olarak adlandırılır (Gass ve Seiter, 2018). Aslında "çok az veya hiç detaylandırmanın olmadığı durumlarda, çok az veya hiçbir iknanın olmayacağını düşünmek mümkündür" (Suher, 2017, s. 27) denilse bile, her bir detaylandırmanın sonucunda iknanın oluştuğunu belirtmek gerekmektedir. Çevresel yol ve sezgisel işleme metotlarında detaylandırmanın düşük olması ikna sürecinde olumsuz bir veriden ziyade olumlu sonuca giden yolu aralama işlevine sahiptir. Bu yollar duygusal verilerin kullanıldığı kişilerin hislerine etki eden bir yol ve işlemeyi kullanır.

Arabalar konusunda bilgi sahibi olan bir kişinin çıkan yeni bir modelle ilgili detaylı bilgi ihtiyacıyla, sürekli üretilen bir model ile ilgili ihtiyacı çok farklıdır. Dolayısıyla bu yol ve işleme kimi zaman oldukça gereklidir. Tam tersi yönde bir örnek olarak ise akıllı telefon ihtiyacı olan bir kişinin yeni telefon ihtiyacında amaç sadece işini görmesi mi? yoksa sosyal statüsünü yükseltecek bir telefon mudur? İşte bu noktada devreye hisler, duygular ve sezgiler girmektedir ve bu da Perloff'un (2014) belirttiği gibi iknanın oluşması için kimi zaman yeterli olabilmektedir. Yine benzer şekilde Gawranski ve Creighton'e (2013) göre detaylandırmanın iknaya etkisinin yanında kimi zaman sezgiler ve çevrenin etkisiyle ikna süreci tamamlanabilmektedir. Sonuç itibariyle ikna süreci oldukça kapsamlı ve çeşitli etki 
dinamiklerinin aracılığıyla farklı durum ve koşullar da farklı şekillerde sonuçlanabilmektedir. Bu anlamda da sürekli ve etkin bir ikna süreci için hedef kitlenin sürekli olarak ihtiyaçlarının farkında olmak, bir anlamda onu gözetlemek ya da verilerini sürekli olarak güncellemek gerekmektedir.

\section{GÖZETIME BAĞLI REKLAMCILIĞIN OLUŞUMU}

Gözetim kavramının geçmişinin oldukça eskiye dayanmasına karşın son yıllarda yeniden büyük bir mesele olarak gündeme gelmekte ve sürekli olarak önemini güncellemektedir. Son dönemde gözetim üzerine çalışmalar özellikle büyük veri (big data) üzerine şekillendiği görülürken; büyük veri ayrıca özellikle sosyal medya üzerinden yeni ve güçlü bir reklam sürecini başlatmıştır. Yakın zamana kadar büyük veriye dayalı reklamcılık herhangi bir sorun olarak görülmezken; bugün durum ciddi ahlaki, yasal ve psikolojik problemlere yol açan ve bir şekilde çözümlenmesi gereken bir durum olarak görülmektedir. 'Peki, sorun ne zaman başladı?' sorusunun cevabı ise David Carroll isimli Amerikalı bir akademisyenin Facebook'tan kendi verilerini istemesi, aynı dönemde Cambridge Analytica ve Facebook skandalının ortaya çıkması durumun geniş kitlelerce fark edilmesini sağlamıştır (Noujaim ve Amer, 2019).

\section{Gözetim ve Büyük Verinin Yaygınlığı}

Gözetime dair çalışmalar neticesinde içinde bulunulan dünyada gözetim artık hem göz ardı edilmeye hem de tam tersi şekilde daha hararetli şekilde tartışılmaya başlanmıştır. Bu tartışmaların ve göz ardı edişin temelinde kişiye sunduğu bazı güvenlik çalışmaları yer alırken diğer yandan ise kişinin özel hayatına doğrudan müdahale edecek çalışmalara da yol açmaktadır.

1791 yılında Jeremy Bentham, Panoptikon çalışmasıyla, bugün de faal olarak kullanılan bir kuram ve kavram ortaya atılmıştır. "Bugüne kadar örneği olmayan, zihin üzerinde, zihinsel iktidar elde eden yeni bir yöntem" (Mattelart, 2012, s. 13) olarak Bentham tarafından açıklanan kavram esas önemini Foucault'un Hapisanenin Doğuşu isimli eseriyle kazanır ve artık Panoptikon maddi bir mekan olmanın ötesinde insanın kendi zihnindedir. Çünkü Foucault, kavramı zihinler içerisinde zaten var olan yapay bir mekan olarak tasvir etmiştir. Daha sonra fikrin, disiplin toplumunun temelini oluşturduğunu söylemektedir ki Mattelart (2012, s. 12-14) bu noktada her kuram ile birleştirilebilecek temel bir paradigma olduğu fikrini öne sürmektedir. Bu paradigma özellikle internetle ve onun ortaya çıkış hikayesiyle değerlendirmeye tabi tutulduğunda anlam kazanmaktadır. Çünkü bu sayede gözetimin sıradanlaşması olgusu ele alınabilmektedir.

Bir güvenlik ve milli gelişmişlik seviyesi göstergesi olarak Amerika'da Savunma Bakanlığının bünyesinde ortaya konan internet, nükleer saldırılara karşı korunma ve farklı bölgelerdeki 


\section{MEDIAJ}

makineleri ortak kullanabilmeyi amaçlayan çalışmalar için yani kısaca bilgi ve haber alma yöntemi olarak ortaya çıkmıştır (Kennedy, 2000 akt. Polat, 2014, s. 13). Snowden'ın ('den akt. Stone, 2016) konuya yönelik çeşitli açıklamalarından anlaşıldığı üzere Amerika'da NSA (National Security Agency- Milli Güvenlik Teşkilatı) çalışanları bile yaptıkları gözetleme eylemlerinin tam olarak farkında değildirler. Yine bu noktada Snowden tarafından ortaya çıkarılmış ısı haritaları Amerika'nın tüm dünyayı nasıl gözetlediğini ortaya koyarken kendilerine koruma kalkanı olarak seçtikleri 'ulusal güvenlik' aldatmacası da ortaya çıkmaktadır. Çünkü ısı haritalarına göre Amerika'nın en çok istihbarat/veri topladığı bölge, pek çok kişinin zannettiği gibi sürekli anlaşmazlık yaşadığı/yaşayabileceği düşünülen bölge ve ülkeler değil yine Amerika'nın kendisidir (Stone, 2016). Güvenlik ve gözetim üzerine başlayan internetin hikâyesinin başlangıcından itibaren bu öğretiler etrafında şekillenmiş olması onun kişisel bilgisayarlar aracılığıyla evlere yayılmasıyla güç kazanmıştır. Bu güç kavramını biraz daha açabilmek için büyük veri ve büyük veriden yararlanmayı sağlayan veri madenciliği tekniğinden bahsetmek gerekir.

Veri madenciliğinde algoritmalar aracılığıyla her türlü veri işleme tabi tutulmaktadır. Algoritmalar benzer nitelikteki verileri kümelendirerek sürekli yeni kategoriler açar. Bu sebeple pek çok kategorizasyon bulunmaktadır. Bu kümelerin ve veritabanlarının hukuki sorunlara yol açtığı ve gerek Avrupa Birliği gerekse uluslararası yasalarla koruma altına alınması gerektiği konusu önemli (Compagnucci, 2020, s. 20-22) olmakla birlikte halen gerekli büyük adımlar atılmamıştır. Çünkü özellikle veri madenciliği konusunda iki büyük firma olan Google ve Facebook, sonradan öğrenildiği üzere pek çok şirkete de veri sağlamaktadır. Google'ın bir arama motoru olması bu şirketin veri toplamasını ve diğer şirketlerle paylaşmasını anlaşııı kılmaktayken, Facebook belirli konularda Google'dan bile üstün bir veri deposu olma özelliğine sahip olması ele alınması gereken bir konudur. Facebook'ta kullanıcıların psikolojik kimliği psiko-grafikler aracılı̆ı̀la çıkarılabilmektedir (Risso, 2018, s. 75-76).

2005 yılında Roger Magoulas tarafından, verinin yoğunluğunu ve boyutunu göz önüne serme amacıyla ortaya konan büyük veri (big data) kavramı ilk olarak 2001 yılında Doug Laney tarafından klasik veri yönetiminin işlersiz kalması üzerine kullanılmıştır. Yapılandırılmış ${ }^{4}$ ve yapılandırılmamış veriler (Ergen, 2018) olarak ikiye ayrılan bu yeni veri türü özellikle yapılandırılmamış kısmıyla büyük şirket ve markaların ilgisini çekmiştir. Site içerisinde yer alan bütün kişisel verileri ve kimi zamansa sitenin mülkiyet sahiplerinin tüm sahibi olduğu sitelerin içerisinde yer alan verileri içeren bu veri türü özellikle Facebook ve Kogan anketi ile tartışılmaya başlanmıştır (Carroll, 2019). Facebook'un psikolojik kimlikleri ile ilgili olarak Cambridge Üniversitesi Profesörü Aleksandr Kogan'ın 2014 yılında oluşturduğu anket sonuçlarından çıkardığı psikolojik profiller örnek gösterilebilir. Bu kimliklerle seçmenlerin bir

\footnotetext{
${ }^{4}$ Yapılandırıımış veriler, banka ödemelerini, sınav sonuçlarını ve kamusal işlemleri ifade ederken bu verilerin dışında kalan çoğu veri yani belirli bir kurala bağlı olmayan veriler yapılandırılmamış yani kişiye özel, kişi tarafından yapılan veriler olarak düşünülebilir.
} 


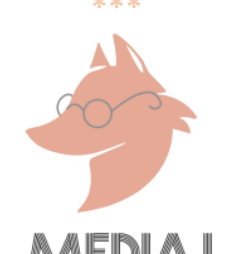

parti ya da adayı desteklemelerine sebep olan kişisel bilgileri elde etmek ve adayların hangi seçmen profillerine sahip olduğunu ortaya çıkarmak amaçlanmıştır. Anketin önemli bir noktası 1 dolar karşılığında ankete katılan 270 bin katılımcının arkadaşlarının da verilerine ulaşılarak toplamda 50 milyon kişinin verisine ulaşılmış olmasıdır. Cambridge Analytica'nın eski CEO'su Alexander Nix (2016) tarafından psikografik şeklinde adlandırılan bu veriler, yine Cambridge Anayltica'nın eski bir çalışanı ve aynı zaman üst düzey yöneticilerinden birisi olan Brittany Kaiser tarafından "silah statüsünde iletişim taktikleri" olarak değerlendirdiklerini ve kullanılmaması gerekli bir işlem olduğunu vurgulamaktadır (Amer ve Noujaim, 2019). Çünkü demografik profil/kimliklere sahip olmanın çok kolay ve artık önemsiz bir hale gelirken Nix'e (2016) göre, esas önemli olanın bir tercihe götüren psikolojik profilleri elde etmektir. Bu psikolojik grafikler hem Trump kampanyasında hem de bu kampanyanın öncesinde farklı ülkeler yaygın şekilde kullanmıştır.

Psikografik veriler, kişinin sevdiği, değer verdiği şeyleri, korkularını, iş ve özel hayatına dair her tür veriyi içermektedir. Bu noktada sadece Nix (2016) ve şirketi için değil, hem siyasi hem de ticari reklamlar açısından oldukça önemlidir. Normal şartlarda bir firma Facebook ya da Instagram'a reklam vereceği zaman kimlere bu reklamın gösterilmesini istediklerini belirtmektedir. Oysa Cambridge Analytica, Facebook'tan kendi geliştirdikleri/geliştirttikleri bir yöntemle kendileri bu verilere sahip olarak istedikleri kitleleri hedeflemiştir. Sürecin bir diğer ihbarcısı Wylie'e ('den akt. Amer ve Noujaim, 2019) göre Cambridge Analytica'yı bir veri bilimi şirketi ya da algoritma şirketi olarak sınırlandırmak büyük bir hatadır. Bu şirket "eksiksiz hizmet sağlayan bir propaganda makinesidir". Kogan'ın testinde ulaşılan veri oranı aslında tüm Amerika'nın kişilik analizini çıkarmak için doğruluk payı yüksek bir ölçek sunmaktadır. Kişiye özel reklam, mesaj, haber gibi her bir kişiye ayrı hizmet sunan bu platformlar aslında birer gözetim şirketidir. Yaptıkları her şey aslında kişilerin verilerinden elde ettikleri psikografiklerin sonucunda gerçekleşmektedir. Carroll'un davası ile ortaya şu sonuç çıkmaktadır; "veri hakları" aslında yeni "insan hakları"dır (Carroll, 2019). Zira Cadwalladr'ın (2019) gerçekleştirdiği çalışmaya göre; Brexit seçiminde İngiltere'nin Avrupa Birliği'nden çıkması yönünde oy kullanan pek çok kişi, kişisel korkularına yönelik Facebook üzerinden gördüğü reklamlara inanarak bu oyları kullanmışlardır. Dolayısıyla Kaiser'ın (2018) dediği gibi hukuk içinde bulunulan süreç içerisinde bireyi koruyacak yasalara sahip değildir. Çünkü büyük veri hukuki açıdan tam olarak anlaşılarak yasalara dahil edilmiş durumda değildir.

Konuyla ilgili olarak bir diğer örnek Rus trol grupları ile ilgilidir. İngiltere'nin Avrupa Birliği'nden ayrılma süreci olarak açıklanabilecek Brexit sürecinde etkin rol aldıkları öğrenilen bu trol grubu Washington Post tarafından ele geçirilen Senato tarafından yayınlanan bir rapora göre 2016 yılındaki seçimlerde her bir sosyal medya platformunu etkin şekilde kullanmıştır. ABD istihbaratı ve Rusya yönetimiyle bağlantılı olan trol grubu özellikle göç ve silahlanma ile ilgili konularda muhafazakârları hedef almıştır. Yine aynı grup Amerika'da Trump kampanyasında Cambridge Analytica benzeri çalışmalarda bulunmuştur (NTV, 2018). 


\section{MEDIAJ}

Verilen bu örnekler birazdan bahsedilecek olan büyük veri reklamcılığıyla ilgili olmakla birlikte bir üründen ziyade ideolojik bir değişim amaçladığı için gözetim başlığı altında verilmiştir. Günümüzde her bir gözetim bir çeşit reklam ve internet ortamındaki her bir reklamda gözetimin sonucudur.

\section{Büyük Veri Reklamcılığı}

Instagram'da yüksek takipçiye sahip bir hesap takibe alındığında o hesaba benzer diğer hesaplarında takibe başlaması, fotoğrafları beğenmeye başlaması; keşfet bölümünde takip ettiğiniz hesaplara, beğendiniz gönderi ve fotoğraflara rastlamak dahası sadece benzer içeriklere sahip olmaları değil kimi zaman aynı renk bütünlüğü ve temalara sahip olmaları... İşte tüm bunlar günümüz sosyal medyasında sıradan kabul edilebilecek şeyler. Çünkü bu durum, herkes tarafından kabul edilmiş olan 'gözetleniyoruz' düşüncesinin tam karşılığıdır.

Kullanıc sitede ne kadar çok vakit harcarsa dikkati yine aynı oranda zayıflayacak ve kendisine ait daha çok veri verecektir. Böylelikle büyük veri güçlenecek ve çok daha etkili tavsiyelerde bulunacak ve en nihai beklenti olarak daha çok para kazanacaktır. Çünkü Google ve Facebook gibi şirketler buralara verilen reklamlardan ziyade bu reklamlara tıklanması üzerinden para kazanırlar. Bu sebepledir ki bu firmalar sürekli olarak algoritmalarını güçlendirirler. Aldatılamayacak kadar güçlü olarak tasarlanmış algoritmalar her geçen gün daha da güçlenerek, sayısız denebilecek oranda kümeye sahiptir. Reklamlar en iyi hedef kitleye algoritma ve yazılım desteği ile otomatik olarak gönderilirler ve tıklanmayı amaçlarlar (Çakır, 2014, s. 95).

Algoritma ya da yazılım desteği olmadan kontrol edilemeyecek veri anlamında da kullanılan büyük veri her geçen saniye biraz daha büyümektedir. Sistem büyüyüp hantallaştıkça çok daha güçlü algoritmalar çok daha etkili ve nokta atışı önermelerde bulunmaktadır. Bu noktada kişinin fikirlerini değiştirecek düzeyde büyük etkiye sahip önermelerden bahsedildiğinin altını çizmek gerekmektedir. Şirketler büyük veriden değişik şekillerde yararlanmaktadır. Palantir şirketi, CIA'ye yardımcı olmak için; Walt Disney, tatil organizasyonlarında; ABD hükümeti bütün bir Amerika'yı yönetmekte; APIXIO isimli şirket ise sağlık sektöründe büyük veriden yararlanırken BBC konulu haber içeriklerindeki veriden yararlanır (Marr, 2016). Burada önemli olan "büyük veri nasıl oluyor da bu kadar geniş bir alanda kullanılabiliyor?" sorusuna cevaben başta Google ve Facebook gibi sürekli trafik akışına sahip site ve siteleri mülkiyetlerinde bulunduran çatı gruplar olmak üzere yukarıda ele alınan Kogan testi dâhil, internet ortamın kişilerin sürekli olarak "dijital ayak izleri" bırakmaları ve büyük veri içerisinde bunların depolanmasıdır. Büyük veriye dayalı reklamcılık çalışmaları Google ve diğer tarayıcılar kadar eski olmasına karşın asıl etkin olarak kullanılıp etkisini daha büyük ölçüde göstermesi özellikle Trump kampanyası ile ortaya çıkmış ve devamında kullanılagelmiştir (Risso, 2018; Amer ve Noujaim, 2019). Burada bir parantez daha açmak gerekiyor. Instagram'daki, Facebook'taki ve 


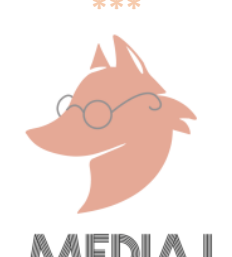

diğer tavsiye içeren her şey aslında büyük veriye dayalı önerileri içerir. Yani kişinin, şahsi verilerinin süzülmesi sonucunda ona en uygun sonuçların gösterilmesi şeklinde gerçekleşmektedir (Ergen, 2018).

Trump kampanyasının önemli olmasının sebebi psiko-grafiklerin etkin kullanımıdır. Psikografiklerin verileri ise Kogan anketi ile erişilen verilerin değişik şirketlere satılmasıyla Cambridge Analytica'ya geçmiştir; yani veriler gayri resmi yollarla elde edilmiştir. Bununla da kalmayarak yine etik olmayan şekillerde başka bir şirkete satılmıştır ve satılan bu şirket bu bilgileri kişilerin kararlarına direkt etki edecek şekilde işleyerek kullanmıştır (Noujaim ve Amer, 2019). Kogan anketi ve Cambridge Analytica ile ilgili pek çok verinin elde edilmesinde etkin rol oynayan David Carroll, the Great Hack isimli belgesel yapımda şu sözleri söylemektedir "Dijital medya ve uygulama geliştiriciliği dersi veriyordum. Bu nedenle çevrimiçi hareketlerimizin verilerinin ortadan kaybolmadığını biliyordum. Derinlere indikçe fark ettim ki varoluşumuzun dijital izleri trilyon dolarlık bir endüstri tarafından işletiliyor. Artık biz ticari ürünüz." (Noujaim ve Amer, 2019).

İnsanı ticari bir ürün olarak gören ikincil tipteki reklamlar insanın dikkatini çekmeyi, takip edilmeyi ve tıklanmayı amaçlar. Tıpkı televizyon reklamlarında olduğu gibi bu reklamlarda da asıl amaç ürün satmak ya da abone çekmektir. Bu anlamda bu reklamların dikkat odaklılığı klasik sistem ile aynıdır. Insanların dikkatini çekme konusunda medyanın yaptıklarını Wu (2017, s. 261), People ve Time Life dergisinin ünlülerin hayatlarını mercek altına alarak büyük satış rakamlarına ulaştıklarını ve çalışanların bunun sebebini anlamadığını aktarmaktadır. Wu (2017), çalışmasında dikkat ekonomisinin farklı bir çalışma prensibinin olduğuna dikkat çekerek kimi insanlar için oldukça sıradan bir şeyin, kimileri için ise oldukça ilgi çekici olabileceğinden bahsederek anlatır. Gerek sosyal medya gerekse Wu'nun (2017) bahsettiği dergiler insanı gözetlemek üzere şekillenmiştir ve gözetlemek günümüz insanının en çok ilgilendiği şeylerden birisidir. Çünkü çok uzun yıllardır radyo, televizyon vb. medyalarla başlayan gözetim günden güne alışıldık ve sıradan bir olgu haline gelmiştir.

Internet, önemli bir iletişimi beraberinde getirirken aynı zamanda, insanın hayatını da kendi esiri haline getirmektedir. Jo-Ellan Dimitrius ve Wendy Patrick Mazzarella (2019, s. 343) çalışmalarına internet ve teknoloji bağımlıı̆ı üzerine okuyucuya birkaç soru sorarak başlar. Konu ile ilgili olarak "Sosyal medya hesaplarınızı kontrol etmek için, gezilerin ardından eve koşarak mı geliyorsunuz?" sorusunu incelemek önemli olacaktır. Soruya akıllı telefonlar aracılığıyla her an sosyal medyasına erişebilecek günümüz insanı "hayır" cevabını verecek olsa da soru yine de önemlidir. Çünkü eve koşarak gelme yerine, 'kendinize gün içinde sosyal medya hesaplarınıza bakmak için ne kadar vakit ayırıyorsunuz?' ya da 'çalışırken /gezerken/ arkadaşlarınızla sohbet ederken sosyal medyanızı kontrol etme ihtiyacı duyuyor musunuz?' şeklinde sorular sorulduğunda cevap "evet" olacaktır ki bu aynı zamanda kişinin kendini gözetlemesi için sisteme ne sıklıkla izin verildiğini gösterir. 
Çalışmanın bir sonraki kısmında insanın hayatının hemen her noktasına dâhil olmayı başaran sosyal medyada yer alan büyük veri reklamları, ikna sürecini ele alan Çift Süreç Teorileri üzerinden incelenecektir.

\section{ARAŞTIRMA}

Araştırma kapsamında ikna sürecinin daha iyi anlaşılabilmesini sağlayan Çift Süreç Teorileri bağlamında büyük veri/hedefli reklamcılığında var olan ikna süreci ele alınmıştır. Çalışmanın metodolojisi nitel araştırma desenine göre şekillendirilerek, yapılandırılmış soru formuna bağlı derinlemesine görüşme tekniği kullanılmıştır. Nitel araştırmalar, ilişkinin öne çıktığı, esnekliğin ve karşılıklı etkileşimin bulunduğu anlam ve yorumlaya imkân veren bir araştırma paradigmasıdır (Balcı, 2018, s. 37). İstanbul ilindeki bir yazılım firmasında çalışan 25 - 30 yaş aralığındaki 15 yazııımcıyla gerçekleştirilen görüşmelerde yedi açık uçlu yöneltilmiştir. Gerçekleştirilen mülakatlarda kişinin sosyal medyada gördüğü reklamların, kişiyi sahip olduğu bilgiler ve yüksek ilgi ile mi yoksa direkt duygularına yönelik mi olduğunu ortaya çıkarmak amaçlanmıştır. Görüşme yapılan isimlerin yazılım mesleğini icra eden kişiler olarak seçilmesinin sebebi; büyük veri algoritmalarını kullanan ya da ortaya çıkaran veri bilimi mesleğine en yakın meslek kolu olmasından dolayıdır. Çalışma amacıyla görüşme yapılan kişilerin isimleri saklı tutularak "K1, K2..." şeklinde numaralandırılmış ve görüşme öncesinde katılımcıların onayı alınmıştır. Aşağıda ele alınan görüşlerinde kısaltma haricinde herhangi bir değişikliğe gidilmemiş ve katılımcıların kendi ifadelerine yer verilmiştir.

Araştırmada elde edilen verilerin analizinde betimsel-yorumlayıcı analiz tekniği kullanılmışır. Betimsel-yorumlayıcı analiz, araştırmacının elde edilen verilerin hepsini değil, onların arasından seçtiklerini belli bir sıraya koyarak yorumladığı analiz türüdür (Sönmez ve Alacapınar, 2018, s. 273). Analizlerde elde edilen verilerin hepsi kullanılmamış, önceden belirlenmiş kategorilere uygun olan veriler alınarak analiz edilmiştir.

Soru formu oluşturulurken ve sonrasında katılımcıların cevaplarının değerlendirilmesinde Cambridge Analytica'nın Brexit kampanyasına yönelik Galler'de bir araştırma gerçekleştiren Cadwalladr'ın (2019) çalışması örnek alınmıştır. Bu çalışmaya göre kişiler belirli konulardaki hassasiyetleri üzerinden etkilenmeye ve ikna edilmeye çalışılmaktadır. Çalışmada göstergebilim, durum analizi ya da içerik analizi tercih edilmemiştir çünkü bu yeni reklamcılık anlayışında "kişiye özel"lik ön plandadır. Yapılan araştırmanında içerik ve sonucundan anlaşılabileceği üzere, her bir kişinin sorulara verdiği cevaplar aslında birbirlerine hem benzer hem de oldukça farklıdır. Televizyon ve gazetede olduğu gibi o kanalı, o gazeteyi izleyen herkesin aynı şeyi görmesinin mümkün olmayışı bu araştırma yöntemlerinin tercihine giden yolu kapatmıştır.

Araştırmanın amacı ve temel sorusu; sosyal medya hesaplarında günlük kullanım esnasında 
karşılaşılan reklamların kişiyi Çift Süreç Teorileri bağlamında hangi yol ya da işlev bağlamında ikna ettiğine yöneliktir. Çift Süreç Teorileri, geneli itibariyle, ikna sürecinin kişide iki farklı şekilde gerçekleşebileceğini öne sürmektedir. Bunlardan ilkinde ikna, kişinin ilgi ve bilgi düzeyinin yüksek olduğu alan ve konularda detaylı bilgi, görüntü ve sesle gerçekleşirken; ikincisinde ise kişinin ilgi ve bilgi düzeyinin düşük veya olmadığı durumlarda duygularına hitap ederek gerçekleşmektedir. Çalışmanın yapılma sebebi de kişilerin sosyal medya reklamlarında hangi türden bir ikna süreci ile karşı karşıya kaldığına yöneliktir. İlgi ve bilgilerinin olduğu mu? Yoksa sadece kişide duygusal bir bağ kurarak yani sosyal medya hesabındaki daha önce paylaşılmış verilerinden hareketle oluşturulmaya çalışılan yeni tasarlanmış ihtiyaçlarına yönelik mi? Yukarıda değinilen Cadwalladr'ın çalışmasında politik bir konuda sosyal medya reklamlarının son derece manipülatif ve duygular üzerinden bir ikna pratiğini gerçekleştirmeyi amaçladığı görülürken, bu çalışmada ise sosyal medya reklamlarının tüketime olan etkisinin hangi ikna pratiğine yönelik olduğunu bulmak amaçlanmıştır.

Yapılan görüşmelerde, görüşme yapılacak kişilerin seçiminde özellikle sosyal medya kullanımının yoğun olduğu 18 - 35 yaş arasındaki kişiler tercih edilmiştir. Cambridge Analytica skandallarının ve Edward Snowden'ın yayınladığı ısı haritalarından hareketle kişilerin seçiminde başka bir kıstas tercih edilmemiştir. Çünkü bu reklamcılık herhangi bir ayrımı kişilerin kontrolü ile değil algoritmalar aracılığıyla otomatik olarak yapmaktadır.

\section{BULGULAR}

\section{Gözetim ve Kullanıcılar}

Görüşme yapılan katılımcılara sorulan ilk soru "Bir alışveriş sitesinde incelediğiniz bir ürünü başka bir sitede görmek; WhatsApp benzeri uygulamalardaki konuşmalarınızda geçen bir ürün ya da hizmetle ilgili sosyal medyada reklamlar görmek artık mümkün. Siz böyle durumlarla karşılaştınız mı? Bunlar bir gözetleme / gözetim faaliyeti olarak kabul edilebilir mi?" şeklindeydi. Bu sorunun sorulma amacı katılımcıların var olan sosyal medya gözetiminin bilincinde olup olunmadığına yöneliktir. Ayrıca bu soru ile sosyal medyadaki reklamların kişisel verileri etkin şekilde kullanıp kullanmadığını anlamak amaçlanmaktadır.

İlk soruya cevap olarak K1 haricindeki tüm katılımcılar bu tarz durumlarla "sürekli olarak" karşılaştıklarını ve "kesinlikle" gözetim olarak sınıflandırdıklarını söylemişlerdir. Bu gözetlemeden K3 şikâyetçi olduğunu belirtirken, K4 "Ölçüsü olması" gerektiğini, K5 "Tüm dünyanın bir gözetim ağına dâhil" olduğunu düşünmekteyken; K7 izlediği bir filmde karakterlerin önemli bir konu hakkında konuşmadan önce telefonlarını mikrodalgaya koyduklarını gördüğünü ve kendisinin bu şekilde gözetlenmeye devam edilmesi halinde bu yola başvuracağını söylemektedir. K11 bu gözetimin aslında yeni olmadığını anca "Yeni bir boyut" olduğunu söylemiş, K15 ise "Sanki içimizde bizimle yaşıyorlar" diyerek endişelerini dile 
getirmiştir. K1 ise izlendiğini - gözetlendiğini hissetmediğini söylemiş olmasına karşın Instagram vb. ortamlarda kendi beğeni ve isteklerine çok benzer içerikleri görmekten rahatsızlık duyduğunu ve bu anlamda küçük bir gözetlemeden bahsetmenin mümkün olacağını söylemiştir.

Katılımcılara sorulan ikinci soru; "Sosyal medyanın büyük veri aracılı̆ııyla kişiye özel reklamcılık anlayışına sahip olduğu biliniyor. Pek çok araştırmacıya göre sosyal medyaları kişi kendisinden daha iyi tanımaktadır. Bu noktada sosyal medya hesabınız sizi ikna ederek bir şey aldırmada ne kadar başarılı? Sizce sosyal medya hesaplarınız sizi, sizden daha iyi mi tanıyor?" şeklindedir. Bu soru ile amaçlanan katılımcıların Cambridge Analytica benzeri kurumların gerçekleştirdikleri davranış değişikliğine giden ikna stratejilerinin farkında olup olmadığına yöneliktir. Yapılan araştırmalar ve literatür taraması sonucunda bilinmektedir ki sosyal medyaları kişilerin bir sonraki hamlelerini kolayca tahmin edebilme yeteneğine sahiptir. Sosyal medyaları kişilerini kendilerinden çok daha iyi tanıyorken; kişileri kullandıkları sosyal medyaları ne kadar iyi tanıyor? Şeklinde de düşünülebilecek olan bu soruya katılımcılar farklı cevaplar vermiştir.

İkinci soruya verilen cevaplardan sorunun ilk kısmı olan sosyal medya hesaplarının katılımcıları ikna etmeye çalışıp çalışmadığına yönelik olarak katılımcılar iki ana gruba ayrıımıştır. K1, K2, K3, $\mathrm{K} 5, \mathrm{~K} 6, \mathrm{~K} 7, \mathrm{~K} 8, \mathrm{~K} 9, \mathrm{~K} 11, \mathrm{~K} 12$ ve $\mathrm{K} 15$ sosyal medya hesaplarının onları ikna etmeye çalıştıklarını ve büyük ölçüde de bu konuda başarılı olduklarını söylerken; K4, K10, K13 ve K14 ise ikna etmeye çalışmadığını söylemiştir. K1 "Fikirlerini değiştirmede" etkili içeriklerle karşılaştığını belirtip "Bir keresinde bir konser için bilet bakarken farklı bir etkinlik dikkatimi çekmiş ve bende incelemiştim. Bir hafta boyunca bana o etkinlik ve etkinlikte sahneye çıkacak kişiler ile ilgili reklamlar gösterdi ki sonunda beni ikna etti diyebilirim" şeklinde bir cevap vermiştir; K3 satın almasını etkileyecek içeriklerle karşılaştığını söylemiştir.

Sorunun ikinci kısmına katılımcılar farklı cevaplar vermiştir. Kimileri sosyal medyalarının içeriklerini kendileri verdiği için, kendilerinden daha iyi tanıyamayacağını düşünürken kimileri, daha iyi tanıdığını, kimileri ise kendileri kadar olmasa çevrelerinden daha iyi tanıdıklarını belirtmiştir. İlk soruya verdiği cevapla kendi içerisinde çelişen K1 "Beni benden daha iyi tanıyamaz. Çünkü ona bilgileri ben veriyorum. Benim verdiğim ölçüde beni tanıyabilir" derken, K4, K10, K14'te benzeri cevaplar vermiş K13 "Zannetmiyorum, benden iyi tanıyamaz" demiştir. K3 "Benden iyi tanıyamasa bile çevremden iyi tanıyor" sözleriyle ve K5, K6 ile K9'da benzeri cevaplar vermiştir. K7 ise "Öyle önerileri oluyor ki bazen şaşırıyorum. Bazen sadece aklımdan geçiyor. Belki de aslında öncesinde bu ikna işlemi için bir zemin hazırlıyorlar. Subliminal mesajlar gibi... Ben düşünmeye başlıyorum, tarayıcıya ya da bir sosyal medya uygulamasında arama yapıyorum ve hemen karşıma benzer ürünler, fikirler belirmeye başlıyor. Çok ilginç!" diyerek konuya yönelik endişelerini dile getirmiştir. K8 ise soruya verilen en ilginç cevaplardan birini vermiştir. $\mathrm{K}^{\prime}$ 'in ifadeleri gerek bu çalışmanın gerekse daha sonra yapılacak çalışmalarının önemini vurgulamaktadır. $O$ "Ben çoğu demografik bilgimi farklı girmeme rağmen gerçek bana 
dair çok fazla şeyle karşılaşıyorum" demiş ve yaptıkları işi "Nokta atışı reklamcılık" olarak değerlendirdiğini söylemiştir. K2 soruya "Hassas olduğum kimseye söylemediğim noktalarımı bile biliyorlar" derken K11, K12 ve K15 "Neredeyse kendilerinden bile iyi tanıdıklarını" düşündüğünü dile getirmiştir.

\section{Satın Alma Eğilimi}

Soru formunda yer alan 3. soru sosyal medyada yer alan büyük veri reklamlarının kişileri ikna etmeye çalışıp çalışmadığına yönelik olarak hazırlanmış ve iki aşamalıdır. "Sosyal medya hesaplarınız sizi belirli konularda ikna etmeye çalışıyor mu? Sürekli belirli konularda reklamlarla karşılaşıyor musunuz?" şeklindeki sorunun ikna çabasına yönelik olan ilk kısmına K14 kesin bir şekilde "Hayır!" derken; K1 "Olayı yeni yeni anlamaya başlıyorum sanırım. Bu sorular birbirlerine benziyor ancak farklı şeyler istiyor. Bu noktada ilk soruya verdiğim cevabı değiştirmek isteyebilirim. Çok fazla benzer içerikle karşılaşıyorum evet beni ikna etmeye çalışıyor" şeklinde cevap vermiştir. Diğer tüm katılımcılar ise sorunun ilk kısmına evet ikna etmeye çalışıyor demiştir. Sorunun ikinci kısmında da ilk kısmında olduğu gibi bir tek K14 sadece belirli konulardaki reklamlarla vs. karşılaşmadığını söylerken diğerleri olumlu cevap vermiştir. Bu cevaplardan bazıları şöyledir... K4 "Vazgeçtiğim şeyleri bile almamı sağlıyor"; K5 "Bilinçaltımı etkileyecek düzeyde"; K7 "Evet, ben o kadar rahatsı oluyorum ki kimi zaman hesaplarımı kapatıyorum, ama çok fazla sürmüyor çünkü herkes orada"; K8 "Ben spesifik bir alana yönelik alışveriş yapan biri olmama yani oyun figürleri araştırıp almama rağmen, bana çok çok iyi önerileri oluyor" ve son olarak K12 "Kullanınca daha iyi bir hayatımın olacağına yönelik bir reklam çabası ile karşılaşıyorum" demiştir.

Katılımcıların sosyal medyada gördüğü reklamlardaki ürünlere yönelik satın alma davranışı ve bu ürünlerin yorumlarına olan ilgi düzeylerini ölçmeyi amaçlayan 4. soru "Sosyal medya reklamlarınızda gördüğünüz bir ürünü almaya eğilimli misinizdir? Gördüğünüz bu ürünü hemen almaya mı çalışırsınız yoksa öncesinde kullanıcı yorumlarına bakar mısınız?" şeklinde iki aşamalıdır.

Kullanıcıların 4. Soruya verdikleri cevaplar, sorunun ilk kısmında 3 ana kategoriye toplanmıştır. Illk kategori almaya eğilimli olanları içermektedir ve K1, K2, K3, K4, K5, K6, K7, K9, K12, K13 kodlu katılımcıları içerirken, kimi zaman etkileyip kimi zaman etkilemediğini söyleyenler K8, K11 ve K14'tür. Son olarak K15 ise satın alma davranışlarında bu reklamların satın alma eğiliminde rol oynamadığı yönünde cevaplamıştır. Katılımcılar soruyu cevaplarken şu sözleri eklemişlerdir; K1 "Kimi zaman fiyat karşılaştırması yapsam da almak isterim"; K4 "Almayacağım varsa da alıyorum bazen ama sosyal medya hesabından değil de eğer varsa web sitesi yoksa da olan sitelerden benzerlerini almaya çalışıyorum"; K5 ise konuyu maddi yönüyle değerlendirerek " $O$ an $k i$ maddi durumumun da etkileri oluyor, $O$ an alamıorsam da kaydediyorum, not alıyorum, durumum olunca alıyorum" şeklinde yanıtlamıştır. 
Sorunun kullanıcı yorumlarını dikkate alıp almama ile ilgili ikinci kısmında da kullanıcılar genel anlamda 3 ana kategoride yanıt vermişlerdir. K3, K6, K7, K10 ve K15 kullanıcı yorumlarını dikkate aldıklarını belirtirken; K2, K12, K13 gerekli durumlarda yorumları okuduklarını ancak çok fazla etkili olmadığı söylemiştir. Son olarak K1, K4, K5, K8, K9, K11 ve K14 genelde okumadıklarını belirtmişlerdir. Soruya yönelik verilen cevaplardan bazıları ise durumun değişik noktalarını ele almada yol göstericidir. K7 “Okuma gibi bir eğilimim var ama her seferinde etkili olmuyor. Yani bu yorumları dikkate alıyor ve önemsiyorum ancak satın almamı etkilemiyor. Bir şeyi alacaksam ve olumlu yorumlar varsa bu içimi rahatlatıyor; eğer ki kötü yorumlar varsa iade prosedürüne dikkat edip alıyorum" şeklinde bir yorumda bulunmuştur. K8 ise "Yorumlar aldatıcı geliyor" demiş ve K14 "Kararsız kalırsam ya da yeterli bilgi yoksa çok nadiren bakıyorum ama dikkate almıyorum. Özenle okumuyorum. Yani bakmıyorum aslında" demiştir. Buradan şöyle bir sonuca varmak mümkündür; kişiler bu yorumlara bakarken çoktan kararını vermiş oluyor ve çoğu zaman bu yorumları içlerini rahatlatmak için okuyorlar.

5 numaralı soru katılımcıların, yalan haber ve yalan reklamlara yönelik fikirlerini almaya yönelik olarak "Sosyal medyadaki reklamlar ve yalan haberler üzerinden bir konu hakkındaki fikriniz değişti mi?" şeklinde sorulmuştur. Bu soruya verilen cevaplarda 3. Ve 4. Sorulara verilen cevaplarda olduğu gibi 3 kategoriye ayrılmış olsa da özellikle bir taraf ağır basmıştır. Katılımcılardan sadece K2 bu tür reklam ve haberlerden etkilenmediğini "Hayır, ben kendimi eğittim. Hemen hemen tüm geleneksel ve yeni medya kanallarını teyit ediyorum" şeklinde verdiği cevapla belirtmiş; K8 ve K12 bu tür reklam ve haberlerle çok fazla karşılaşmadıklarını ya da karşılaşsalar bile yalan olup olmadıklarını değerlendirecek bilgiye sahip olmadıklarını söylemişlerdir. Geriye kalan on iki katılımcı ise bu tür reklam ve haberlerden etkilendiklerini ve genelde de doğrusunu öğrenmeleri durumunda bile eski iyi/kötü etkinin devam ettiğini ve fikirlerini değiştiremediklerini söylemişlerdir.

Soruya verilen cevaplardan bazıları şu şekilde... K1 "Çoğunlukla yalan haber olduğunu bilemiyorum çünkü yoğun çalışıyorum. Gerçeği öğrenince ise etkisinden çıkmam çok mümkün olmuyor"; K3 "Etkilenince teyit sitelerini önermeye başladı çevrem. Ancak etkilerinden çıkmam mümkün olmuyor"; K7 kodlu katılımcı ise en farklı cevabı "Değişiyor, sonra yine değişiyor ancak ilk etkiyi kaybetmiyor. Üzerine düşününce gerçek aklıma geliyor. Ancak konu ile ilgili önce yanlış olan şeyler geliyor aklıma" şeklinde vermiştir.

\section{Duygusal İçerikler ve Arzu Nesneleri}

Kişinin bilgilendirici reklamlarla mı yoksa duygusal içeriğe sahip reklamlarla mı karşılaştığının bulunmaya çalışıldığı 6 . Soru katılımcılara "Sosyal medyadaki reklam ve öneriler fikir ve bilgi sahibi olduğunuz konularda, duygusal içeriklerle mi yoksa sizi daha fazla bilgilendiren içeriklerle mi karşılaşıyorsunuz?" şeklinde sorulmuştur. Soruya yalnızca K6 her iki reklam türüyle karşılaştığını belirtmiş; yine yalnızca K14 bilgilendirici reklamlarla karşılaştığını 


\section{MEIDIAJ}

belirtirken diğer katılımcıların tamamı duygusal içerikli reklamlarla karşılaştıklarını hatta K4, K5 ve K12 arzu uyandıran reklamlarla karşılaştıklarını belirtmiş; K11 ise hiç bilgilendirici reklamla karşılaşmadığını aktarmıştır.

K6 kodlu katılımcı "Genelde duygusal reklamlarla karşılaşıyorum. Bilgilendirici reklamlar ise daha çok aldığım bir ürünün rakip markasına ait ya da aynı markaya ait aldığım üründe daha üst bir model ya da versiyona ait oluyor ve çok az karşılaşıyorum" şeklinde konuyu özetlemiştir. K4, K5 ve K12 arzu uyandıran ürün tanımını ise, reklamlarda kullanılan ürünlerin hayata farklı bir bakış kazandırdığını ve ucuz bir ürün bile olsa onu kullanınca statüsünün yükseleceğine ya da yüksek sınıf kişilerin kullandığı bir ürünün kendi sınıflarına göre fiyata sahip bir muadili olduğuna yönelik kişiyi teşvik ettiğini söylemektedirler. K12 bu noktada farklı bir konuya da değinerek "Öyle reklamlarla karşılaşıyor ki insan, onu arzulamanın ötesinde sanki almazsam, kullanmazsam, o hizmetten faydalanmazsam olmayacakmış; hayatımda bir şeyler eksik kalacakmış kendimi yitik hissedecekmişim gibi hissettiriyor" şeklinde açıklamıştır.

\section{Korku: Duygusal İçeriklere Farklı Bir Değer Biçme}

Katılımcılara sorulan son soru "Sosyal medya reklam ve önerilerinde korkularınızı tetikleyici içeriklerle karşılaşıyor musunuz? (Korku ile kastedilen fobi tarzı içerikler değil. Örneğin kilo almanız, sağlığınız, deprem, su baskını, göçmenlik vb. dolaylı ve direkt sizi etkileyebilecek konular ve satın almazsanız olabilecek durumlar gibi) Ya da bir ürün veya hizmeti arzular/aşırı ister/ister duruma geliyor musunuz?" şeklinde sorulmuştur. Bu soru özellikle literatür kısmında ele alınan Carole Cadwalladr'ın çalışmasında ortaya çıkan, kişilerin aslında olmayan konuları, duygularına yoğun müdahaleler ile korku dürtüsünü uyandırmaya yönelik içeriklerin Türkiye'de satın alma davranışı için de kullanılıp kullanılmadığını bulmaya yöneliktir.

Katılımcılar son soruya 3 ana ayrı cevap vermişlerdir. K2 bu tarz reklamlarla hiç karşılaşmadığını belirtmiş. K1, K9, K13, K14 ve K15 bu tarz reklamları gördüklerini ancak etkilenmediklerini belirtmiş ve geri kalan 9 katılımcı ise bu tür reklamlardan etkilendiklerini aktarmışlardır. K7 ve K8 seçim dönemlerinde bu tarz içeriklerle sıklıkla karşılaştıklarını sonrasında ise ara ara karşılaştıklarını belirtmiştir. K10 yakın zamanda olmasa da böyle içeriklerle karşılaşmanın "Endişe verici ve anksiyetemi körükleyici" şeklinde tanımlamış K11 ise "Bitkisel içerikli vitamin alacaktım neredeyse, arkadaşlarıma sizde alsanıza dediğimde duruma yönelik pek çok şey anlattılar meğer bunlar aldatıcıymış" sözleriyle başından geçen yakın zamanlı bir olayı aktarmıştır. K13 ise sadece futbol, oyun ve oyun figürü hesaplarını takip edip başka şeylere yönelik herhangi bir şeyi beğenmediği ve araştırmadığı için böyle şeylerle karşılaşmadığını belirtmiştir.

Tüm bu sorular ve katılımcıların verdiği yanıtlar sonucunda görülmektedir ki, Çift Süreç Teorileri'ne bağlı olarak çevresel yol ve sezgisel işleme, kişileri ikna etmede büyük veri 
reklamcılığında ağırlıklı olarak kullanılmaktadır. Merkezi yol ve sistematik işleme ise nadiren, rakip markalar ve üst modellerin kullanımına teşvik amaçlı kullanılmaktadır.

\section{DEĞERLENDIRME VE SONUÇ}

Çift Süreç Teorileri kapsamında ikna süreçlerinin incelendiği bu çalışmada sözü geçen büyük veri - hedefli reklamcılık, hem geçmiş siyasi seçimlerde önemli rol oynamış; hem de kişilerin yeni bir tüketim dalgasına yönlendirilmesinde anahtar görevi üstlenmiştir. İkna edilebilirliğin görsellik üzerinden ilerlemesini iyi bir şekilde sistemleştirerek dünyayı yeni bir tüketim dalgası içerisinde yönetmeye çalışan güç çevreleri kişileri sürekli olarak duygular üzerinden kontrol etmeye yönelmektedir.

Yapılandırılmış soru formuna göre gerçekleştirilen görüşmelerde katılımcıların verdiği yanıtlar sonucunda görülmektedir ki, büyük veri reklamcılığı kişileri tüketime yönelik olarak fazlasıyla etkilemektedir. Gözetim kavramının içinin boşaltıldığı daha doğrusu önemsizmiş gibi gösterilmeye çalışıldığı günümüzde kişisel veriler, yeni insan hakları olarak adlandırılırken; görülmektedir ki henüz yasa koyucular, reklam verenler ve sosyal medya şirketlerince yeterince önemsenmemektedir.

Yapılan çalışmada bireylerin aslında gözetim konusunun farkında olduğu ancak buna rağmen sosyal medyalarını kullanmaya devam ettiği görülmektedir. Gözetime yönelik olarak sorulan ilk soruya verdikleri cevap, doğrudan bir şekilde gözetlemeden rahatsılıklarını dile getiren katılımcılar kendi zevk ve tercihlerine göre ürün reklam ve tanıtım faaliyetleri ile karşılaştıklarını söylemektedirler. Buna ek olarak da satın alma davranışlarını etkileyecek düzeyde bir ikna ile karşı karşıya geldiklerinden söz etmektedirler. Tüm bu yöndeki davranışlar, psikografiklerin kişileri ikna etme anlamında halen etkin şekilde kullanıldığını göstermektedir. Korkunun özellikle duygulara hitap edecek şekilde, kişilerin zayıf noktaları üzerinden ilerlediği de görülmektedir. Bu nokta önemlidir, çünkü Cadwalladr'ın yürüttüğü çalışmada göstermiştir ki Brexit kampanyasında gerçek olmayan konular kişilerin duygusal açıkları üzerinden ikna edilmelerinde kullanılmıştır ki bu da psikografiklerin yoğun şekilde kullanımının devam ettiğini göstermektedir.

Psikografikler vasıtasıyla nokta atışı ikna stratejilerinin mümkün olmasını da katılımcıların, "Kendimi vazgeçsem bile almaya karar vermiş şekilde buluyorum" vb. açıklamaları mümkün; yine bir kullanıcının başka bir amaçla girdiği sitede farklı bir ürünü incelemesi ile bir hafta boyunca o ürüne yönelik reklamlarla karşılaşıp sonucunda ikna olarak o ürünü almaya ikna olmuştur. Bir başka katılımcı ise bu reklamları subliminal mesajlar göndermekle yargılamıştır. Bu çalışma kapsamındaki amaç bu olmadığı için üzerinde durulmamış olmasına rağmen; ileride bu noktada da bir çalışma yapmak konuya açıklık getirmesi anlamında oldukça önemli olabilir. 
Çalışma kapsamında değerlendirmeye alınan büyük veri reklamcılığı sistemli bir şekilde duygular üzerinden hareket etmektedir. Çift Süreç Teorilerinde yer alan çevresel yol ve sezgisel işlemenin bu reklam sürecinde aktif olarak tercih edilmesi, sosyal medya kullanıcılarının bilgi içerikli reklamlarla çok az karşılaşması ya da karşılaşsalar bile bunun genellikle rakip markalar ve üst modelleri için olduğu ortaya çıkmıştır.

Derinlemesine düşünme ve bilgi sahibi olma durumlarında kişileri ikna etmede görev üstlenen merkezi ve sistematik işleme yöntemleri büyük veri reklamcılı̆ında oldukça kısıtlı şekilde kullanıldığı yapılan çalışma sonucunda görülmüştür. Bu yöntemlerin kullanılmasında gereken kişide yeterli bilgi düzeyinin olması ve zor ikna edilebilme ihtimaline yönelik olarak daha fazla bilgi aktarımının sağlanması; buna karşı sosyal medyadaki büyük veri reklamcılığııın kişilerin duygularını açığa çıkartıp, ürünleri arzulamalarını sağlayan bir yol tercih edilir.

Çalışmanın araştırma bölümünün reklam literatüründe yakın zaman içerisinde ele alınmaya başlanan büyük veri reklamlarının ikna sürecinin ne şekilde işlediğini ele alış biçimi açısından alana katkı sağlayarak yeni araştırmalara yol göstereceği düşünülmektedir.

\section{KAYNAKÇA}

Aksu, H. (2016). Big data: bilginin gücü. İstanbul: Pusula Yayıncılık.

Amer, K., ve Noujaim, N. (Yönetenler). (2019). The Greate Hack [Sinema Filmi].

Aristoteles. (2014). Retorik (12 b.). (M. Doğan, Çev.) İstanbul: Yapı Kredi Yayınları.

Balcı, A. (2018). Sosyal bilimlerde araştırma yöntem, teknik ve ilkeler. Ankara: Pegem Akademi.

Cadwalladr, C. $(2019,04)$. Facebook's role in Brexit. TED:

https://www.ted.com/talks/carole_cadwalladr_facebook_s_role_in_brexit_and_the_threat_to _democracy\#t-903329 adresinden alındı.

Carroll, D. $(2019,04)$. Democracy under attack: One man's journey to get his data back. TEDxMidAtlantic:

https://www.ted.com/talks/david_carroll_democracy_under_attack_one_man_s_journey_to_ get_his_data_back adresinden alındı.

Compagnucci, M. C. (2020). Big data, databases and "Ownership" right in the cloud. (A. Zavrsnik, Dü.) Singapore, Singapore: Springer - Kyushu University.

Çakır, M. (2014). Yeni medyaya ilişkin eleştirel yaklaşımları ve tespitleri ile Christian Fuchs. M. Çakır içinde, yeni medyaya eleştirel yaklaşımlar (s. 81-130). İstanbul: Doğu Kitabevi.

Dimitrius, J. E., ve Mazzarella, W. P. (2019). Insanı okumak. İstanbul: Koridor Yayıncılık. 


\section{MEDIAJ}

Ergen, Y. (2018). büyük veri, sosyal medya ve etik: Facebook örneğinde bir değerlendirme. Yeni Düşünceler Dergisi, 53 - 64.

Fennis, B. M., ve Stroebe, W. (2010). The psychology of advertising. Amerika: Psychology Press.

Gass, R. H., ve Seiter, J. S. (2018). Persuasion (social influence and compliance gaining (6 b.). New York : Routledge.

Gawronski, B., ve Creighton, L. A. (2013). Dual process theories. D. E. Carlston içinde, The oxford handbook of social cognition (s. 282-312). Amerika: Oxford University Press.

Kaiser, B. (2018). hukuk sizi korumaz. 12 01, 2019 tarihinde https://www.youtube.com/watch?v=Juwp6fhn6bc adresinden alındı.

Karadoğan Doruk, E. (2015). iknanın sosyal psikolojisi (temel kavramları ve kuramlarıla). İstanbul: Derin Yayınları. Press.

Kruglanski, A. W. (2004). The psychology of closed mindedness. New York: Psychology

Marr, B. (2016). Büyük veri iş başında: 45 yıldız şirket büyük veriyi nasıl kullandı? (B. Gündüz, Çev.) İstanbul: Mediacat Yayınları.

Mattelart, A. (2012). Gözetimin küreselleşmesi: güvenlileştirme düzeninin kökeni. İstanbul: Kalkedon Yayınları.

Nix, A. (2016, 09 27). Cambridge Analytica - The power of big data and psychographics. Concordia - YouTube Hesabı: https://www.youtube.com/watch?v=n8Dd5aVXLCc adresinden alındı

NTV. (2018, 12 17). 10 21, 2019 tarihinde ABD seçimlerine Rus müdahalesinden YouTube, Tumblr, Pinterest, Instagram ve Google+ etkilendi iddiası: https://www.ntv.com .tr/dunya/abdsecimlerine-rus-mudahalesinden-youtube-tumblr-pinterest-instagram-vegoog,kAt4EJRE1kSbxsALPkCOOw adresinden alındı.

Perloff, R. M. (2014). The dynamics of persuasion - Communication and Attitudes in The 21st Century (5 b.). Routledge.

Polat, N. (2014). İnternetin alışkanlıklarımız üzerine etkileri. Selçuk Üniversitesi Iletişim Fakültesi Akademik Dergisi, 2(2), 12-22.

Risso, L. (2018). Harvesting your soul? Cambridge Analytica and Brexit. C. Jansohn (Dü.) içinde, brexit means brexit: selected proceedings of the symposium (s. 75-90). Mainz: Akademie Der Wissenschaften und Der Literatur.

Seker, S. E. (2014). Çift süreç teorileri (dual proces theories). YBS Ansiklopedisi, 1(1). 


\section{MEDIAJ}

Sönmez, V., ve Alacapınar, F. (2018). Örneklendirilmiş bilimsel araştırma yöntemleri. Ankara: Anı Yayınları.

Stone, O. (Yöneten). (2016). Snowden [Sinema Filmi].

Suher, K. (2017). Çift süreç teorileri (Dual Proces Theories). A. A. Bir, ve K. Suher içinde, reklam teorileri (s. 13-81). İstanbul: The Kitap Yayınları.

TDK Sözlük. (2021). 02 18, 2021 tarihinde TDK: https://sozluk.gov.tr/ adresinden alındı

Wu, T. (2017). Dikkat tacirleri. İstanbul: The Kitap Yayınları. 